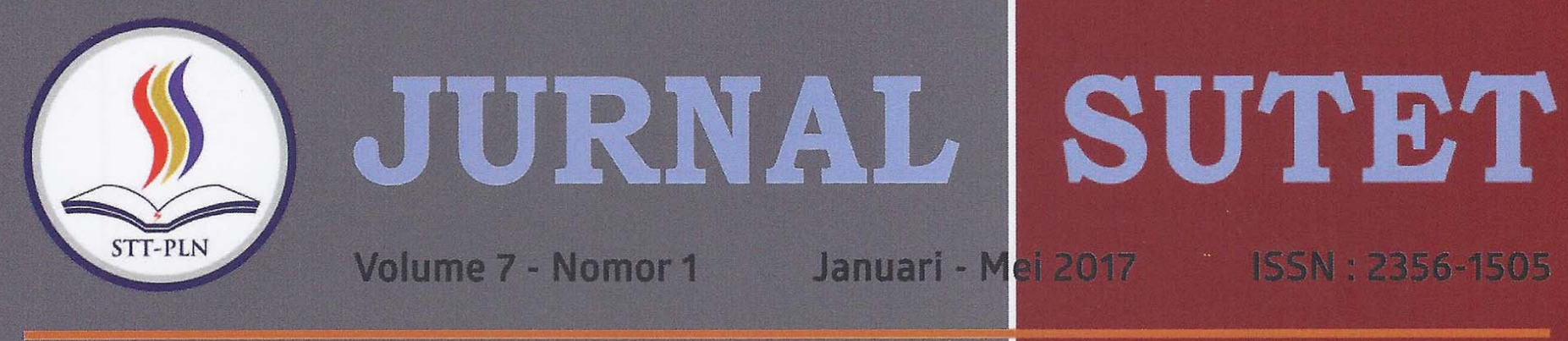

DESAIN SISTEM ALARM MOBIL BERBASIS SMS

Erlina; Hendrianto Husada; Bambang Tri Atmodjo

KELAYAKAN PENGGUNAAN PENDINGIN THERMOELEKTRIK UNTUK PENGHEMATAN DAYA LISTRIK PADA BASE TRANSCEIVER

Sunaryo; Uno Bintang Sudibyo; Supriadi Legino

WITRICITY (WIRELESS ELECTRICITY)

Aas Wasri Hasanah; Oktaria Handayani

CONCEPTUAL DESIGN FOR MITIGATING HARMONIC DISTORTION ON ESP INSTALLATION: CASE STUDY IN KAJI SEMOGA FIELD, MEDCO E\&P INDONESIA

Sandy Suryakusuma; Suprapto Atmowiranto; Dadang Darmawan

RANCANGAN RANGKAIAN ANTI BOUNCING UNTUK RANGKAIAN DIGITAL

Tasdik Darmana

STUDI POWER WHEELING DIKAWASAN INDUSTRI JABABEKA

Bimo Brillianta; Uno Bintang Sudibyo; Wildan Aripin

PEMASANGAN ARRESTER DAN ARCING HORN PADA PENGHANTAR BERISOLASI DI SUTM $20 \mathrm{kV}$ Christine Widyastuti; Andi Makkulau

PENGELOLAAN EMISI GAS LANDFILL (BIOGAS) SEBAGAI ENERGI TERBARUKAN Isworo Pujotomo; Muchamad Nur Qosim

DISAIN SISTEM PENTANAHAN PROTEKSI PETIR SISTEM MULTIPLE VERTICAL ELECTRODES PADA TERMINAL LAWE-LAWE - PERTAMINA DHP

Ibnu Hajar

ANALISA DCS (DISTRIBUTED CONTROL SYSTEM) PADA PROSES POLIMERISASI

Syarif Hidayat; Irsyadi Akbar Jay

PENGEMBANGAN TEKNOLOGI SISTEM SMART MICROGRID DI SEKOLAH TINGGI TEKNIK PLN Heri Suyanto; Agung Hariyanto

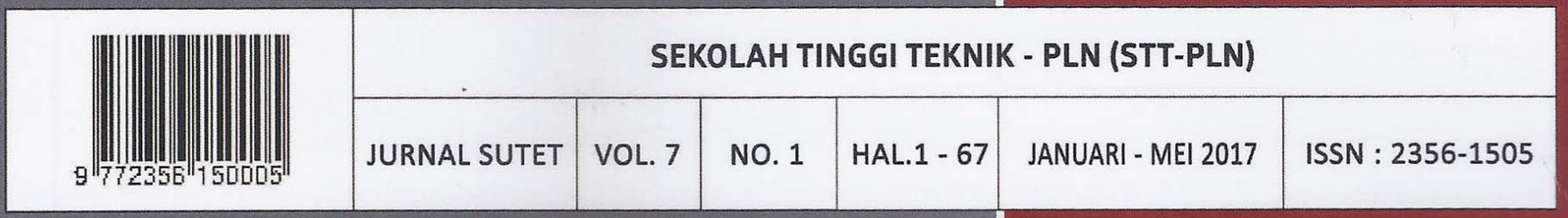




\title{
CONCEPTUAL DESIGN FOR MITIGATING HARMONIC DISTORTION ON ESP INSTALLATION: CASE STUDY IN KAJI SEMOGA FIELD, MEDCO E\&P INDONESIA
}

\author{
Sandy Suryakusuma1) \\ Magister Teknik Elektro, STT PLN \\ reade_14@yahoo.com \\ Suprapto Atmowiranto ${ }^{2)}$ \\ Surface Facilities Engineering, Medco Energi \\ suprapto.atmowiranto@medcoenergi.com \\ Dadang Darmawan ${ }^{3)}$ \\ Surface Facilities Engineering, Medco E\&P Indonesia \\ dadang.darmawan@medcoenergi.com
}

\begin{abstract}
Abstrak : Meningkatnya penggunaan beban non-linier dalam instalasi kelistrikan mengakibatkan masalah distorsi harmonik dalam sistem kelistrikan industrial dan komersial.Beban non-linier yang banyak digunakan dalam operasi minyak dan gas bumi adalah variable speed drive (VSD) dan uninterruptible power supply (UPS).
\end{abstract}

PT Medco E\&P Indonesia memberdayakan Electrical Submersible Pump (ESP) sebagai metode produksi minyak bumi yang diterapkan di lapangan produksi Kaji Semoga. Instalasi ESP dilengkapi dengan VSD sebagai pendukung asut dan pengendali kecepatan motor penggerak ESP demi mencapai besaran produksi minyak bumi.

Operasi VSD membangkitkan gangguan harmonik yang dapat mengganggu sistem daya listrik seperti panas berlebih dari peralatan listrik, kegagalan prematur pada peralatan berputar dan pembatas arus yang gagal kerja. Pada umumnya untuk mengendalikan masalah ini, harmonic filter dipasang untuk mengkompensasi distorsi harmonik. Instalasi harmonic filter berkontribusi pada biaya pemeliharan kehandalan sistem daya listrik di lapangan produksi Kaji Semoga.

Makalah ini menjabarkan metode-metode alternatif untuk mengendalikan distorsi harmonik dalam sistem distribusi daya lsitrik termasuk pemasangan harmonic filter. Metode untuk mengendalikan distorsi harmoniktersebut termasuk penggunaan trafo phase-shifting. Metode lain untuk menanggulangi distorsi harmonik adalah merancang ukuran konduktor selain sebagai proteksi arus beban-lebih juga bisa menerima pengaruh harmonic pada arus beban.

Metode-metode alternatif ini bisa mengurangi biaya dari usaha menghilangkan distorsi harmonik secara signifikan.

Kata kunci: harmonik, VSD, trafo, konduktor

\section{INTRODUCTION}

Non-linier loads widely used in oil and gas operation are variable speed drive (VSD) and uninterruptible power supply (UPS). PT Medco E\&P Indonesia is utilizing Electrical Submersible Pump (ESP) as one of artificial lift method in Kaji Semoga Field. Since 2010, number of ESP installation in Kaji-Semoga field is significantly increases. Unit of ESP utilizes VSD for its motor starter and speed controller in order to achieve required production rate. Meanwhile, VSD operation itself generates harmonic interference which may disturb the power system.

Latest comprehensive harmonic measurement and analysis was conducted in 2013. In period of 2014-2016, more than 50 black outs was occurred. Some of them are suspected due to harmonic interference, as shown in Table 1. 
Table 1. Simplified black out event in kajisemoga field in period of 2014-2016

\begin{tabular}{|l|l|l}
\hline PERIOD & NUMBER OF BLACK OUT & PRODUCTION DEFERMENT [BBLS]
\end{tabular}

\begin{tabular}{|l|l|l|}
\hline 2014 & 12 & 24.188 \\
\hline 2015 & 19 & 81.039 \\
\hline 2016 & 25 & 85.953 \\
\hline
\end{tabular}

The consequence was approximately 191,181 bbls of crude oil deferment in Kaji Semoga field. Installing harmonic filter is a common practice taken to overcome harmonic distortion. Some of alternative method will be discussed afterward.

\section{BASIC THEORY AND DISCUSSION}

Power system harmonics are defined as sinusoidal voltage and currents at frequencies that are integer multiples of the main fundamental frequency, which is $60 \mathrm{~Hz}$ at Kaji-Semoga field, as illustrated on Figure 1.

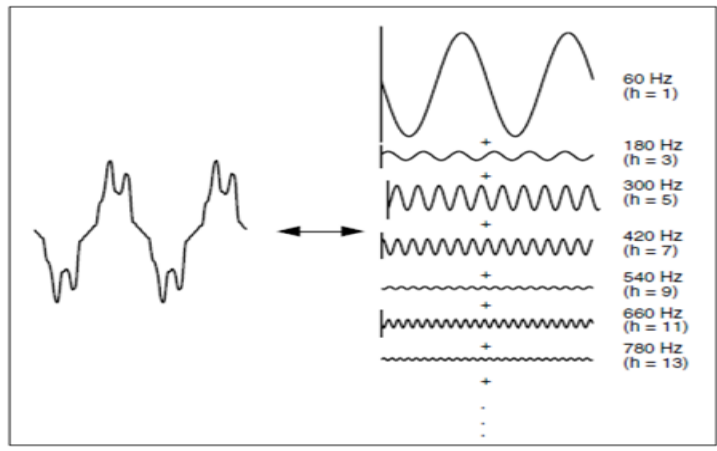

Figure 1. Distorted waveform caused by harmonic

As mentioned regarding comprehensive harmonic measurement and analysis in 2013, Table 2 is showing the simplified result of the measurement. Two of installed ESP unit, measured with very excessive result.

Table 2. Modified sampling harmonic measurement result of ESP unit in KajiSemoga field

\begin{tabular}{|c|c|c|c|c|c|}
\hline No. & Description & Measured Point & THDV & THDi & TDD \\
\hline 1 & ESP 1 & outgoing of VSD & $100 \%$ & $43.1 \%$ & $6.7 \%$ \\
\hline 2 & ESP1 & incoming of VSD & $5.3 \%$ & $4.9 \%$ & $4.9 \%$ \\
\hline 3 & ESP2 & outgoing of VSD & $100 \%$ & $80.5 \%$ & $59.2 \%$ \\
\hline 4 & ESP2 & incoming of VSD & $5.1 \%$ & $5.3 \%$ & $5.3 \%$
\end{tabular}

At the outgoing of VSD shows THDv of $100 \%$. Detailed inspection identified both ESP unit were not equipped with harmonic filter. As some actions were taken to resolve, unfortunately in the next three years number of black out were getting worse as shown in Table 1.

Ideally, the harmonic distortion is caused by non-linear devices which can be categorized into:

1. Saturated (in the iron-core) magnetic devices, such as generators, transformer, and motors.

2. Power electronic devices switching; such as compact fluorescent lamp, rectifier and VSD.

The value of Total Harmonic Distortion (THD) is defined as the ratio of the sum of the powers of all harmonic components to the power of the fundamental frequency. Ilustration of THDv and THDi according to IEEE 519, is shown on Table 3 and Table 4.

Table 3. Voltage distortion limit (source IEEE 519)

\begin{tabular}{|c|c|c|}
\hline Bus voltage $V$ at PCC & $\begin{array}{c}\text { Individual } \\
\text { harmonic (\%) }\end{array}$ & $\begin{array}{c}\text { Total harmonic } \\
\text { distortion THD (\%) }\end{array}$ \\
\hline$V \leq 1.0 \mathrm{kV}$ & 5.0 & 8.0 \\
\hline $1 \mathrm{kV}<V \leq 69 \mathrm{kV}$ & 3.0 & 5.0 \\
\hline $69 \mathrm{kV}<V \leq 161 \mathrm{kV}$ & 1.5 & 2.5 \\
\hline $161 \mathrm{kV}<V$ & 1.0 & $1.5^{2}$ \\
\hline
\end{tabular}

${ }^{2} \mathrm{High}$-voltage systems can have up to $2.0 \%$ THD where the cause is an HVDC terminal whose effects will have attenuated at points in the network where future users may be connected

Table 4. Current distortion limits for systems rated $120 \mathrm{~V}$ through $69 \mathrm{kV}$ (source IEEE 519)

\begin{tabular}{|c|c|c|c|c|c|c|}
\hline \multicolumn{7}{|c|}{$\begin{array}{c}\text { Maximum harmonic current distortion } \\
\text { in percent of } I_{\mathrm{L}}\end{array}$} \\
\hline \multicolumn{7}{|c|}{ Individual harmonic order (odd harmonics) } \\
\hline$I_{\mathrm{SC}} / I_{\mathrm{L}}$ & $3 \leq h<11$ & $11 \leq h<17$ & $17 \leq h<23$ & $23 \leq h<35$ & $35 \leq h \leq 50$ & $\mathrm{TDD}$ \\
\hline$<20^{\mathrm{c}}$ & 4.0 & 2.0 & 1.5 & 0.6 & 0.3 & 5.0 \\
\hline $20<50$ & 7.0 & 3.5 & 2.5 & 1.0 & 0.5 & 8.0 \\
\hline $50<100$ & 10.0 & 4.5 & 4.0 & 1.5 & 0.7 & 12.0 \\
\hline $100<1000$ & 12.0 & 5.5 & 5.0 & 2.0 & 1.0 & 15.0 \\
\hline$>1000$ & 15.0 & 7.0 & 6.0 & 2.5 & 1.4 & 20.0 \\
\hline
\end{tabular}

${ }^{2}$ Even harmonics are limited to $25 \%$ of the odd harmonic limits above.

${ }^{b}$ Current distortions that result in a dc offset, e.g., half-wave converters, are not allowed.

'All power generation equipment is limited to these values of current distortion, regardless of actual $I_{x_{x}} / I_{L}$

where

$I_{x_{x}}=$ maximum short-circuit current at PCC

$I_{\mathrm{L}}=$ maximum demand load current (fundamental frequency component)

at the PCC under normal load operating conditions

The following information will determine the effect of harmonics which might cause some of the black out in KajiSemoga. 


\subsection{Harmonic Effect on Motors and Generators}

Harmonic pairs, such as the fifth and seventh harmonics, have the potential for creating mechanical oscillations in a motor-load system. The fifth and seventh harmonics can combine to produce a torsional stimulus on the rotor at the sixth harmonic frequency. If the frequency of a mechanical resonance exists close to the frequency of electrical stimulus, highstress mechanical forces can be developed accordingly, such as a premature bearing damage.

\subsection{Harmonic Effect on Transformers}

The overall effect is an increase in the transformer heating above its nominal operating temperature at the same load, as compared to purely sinusoidal (fundamental) operation. Therefore, it will decrease equipment lifetime.

\subsection{Harmonic Effect on Switchgear and Relaying}

As with other types of equipment, harmonic currents can increase heating and losses in switchgear, thereby reducing steady-state current carrying capability and shortening the life of some insulating components. Fuses suffer a derating because of the heat generated by harmonics during normal operation.

IEEE 519 mentions the effects of harmonics on relay operation as follows:

1. Relays exhibit a tendency to operate slower with higher pickup values

2. Static under-frequency relays are susceptible to substantial changes in operating characteristics.

3. In most cases, the changes in operating characteristics are relatively small over the moderate range of distortion expected during normal operation (e.g., $5 \%$ harmonic factor).

4. For different manufacturers, overvoltage and overcurrent relays exhibit different changes in operating characteristics.

5. Harmonics sometimes impair the high-speed operation of differential relays. Some tests demonstrate that the relays could exhibit complete restraint.
In general, distortion factors of $20 \%$ will cause problems in protective relay operation.

\subsection{Harmonic Effect on Cable}

Losses are increased in conductors and equipment which carrying harmonic currents, resulting in temperature rise. The causes of the additional losses include:

1. A disturbance in overcurrent protection is leading to circuit breaker and fuse nuisance tripping;

2. An increase in the root mean square (rms) value of the current for an equal active power consumed;

3. An increase in the apparent resistance of the core with frequency, due to the skin effect;

4. An increase in dielectric losses in the insulation with frequency, if the cable is subjected to non-negligible voltage distortion;

5. A phenomenon related to the proximity of conductors with respect to metal cladding and shielding earthed at both ends of the cable, etc.

Generally speaking, harmonics have a major economic impact:

a) Premature ageing of equipment means it must be replaced sooner unless oversized right from the start.

b) Overloads on the distribution network can require higher subscribed power levels and increase losses.

c) Distortion of current waveforms provokes nuisance tripping that can stop production

\section{METHOD AND COMPARISON: MINIMIZING HARMONIC DISTURBANCE}

The most frequently encountered harmonics in three-phase distribution networks are the odd orders. Harmonic amplitudes normally decrease as the frequency increases. Above order 50, harmonics are negligible and measurements are no longer meaningful. Sufficiently accurate measurements are obtained by measuring harmonics up to order 30. Utilities monitor harmonic orders $3,5,7,11$ and 13. Generally speaking, harmonic conditioning of the lowest orders (up to 13) is sufficient. 
Common method taken to reduce harmonic distortion is by installing harmonic filter.

Alternative methods to reduce harmonic distortion effect are oversizing the equipment and installing phase shifting transformer.

\subsection{Oversizing the Equipment}

Derating of power sources (generators, transformers and UPS) means they must be oversized.

Conductors must be sized taking into account the flow of harmonic currents. In addition, due the skin effect, the resistance of these conductors increases with frequency. To avoid excessive losses due to the Joule effect, it is necessary to oversize conductors. To overcome heating effect of harmonic distortion, flow of harmonics in the neutral conductor means that it must be oversized.
In general next bigger size of cable should be selected. Generally speaking, all electrical equipment (electrical switchboards) subjected to voltage harmonics or through which harmonic currents flow, exhibit increased energy losses and should be de-rated, if necessary.

\subsection{Phase Shifting Transformers}

The harmonic currents of several converters combine vectorially at the common supply busbars. Their phases are generally unknown except for the case of diode rectifiers. It is possible to attenuate the 5th and 7th current harmonics using two equally loaded 6-pulse diode bridges, if the couplings of the two power supply transformers are carefully chosen. Proposed modification in Kaji-Semoga Field refers to Figure 2.

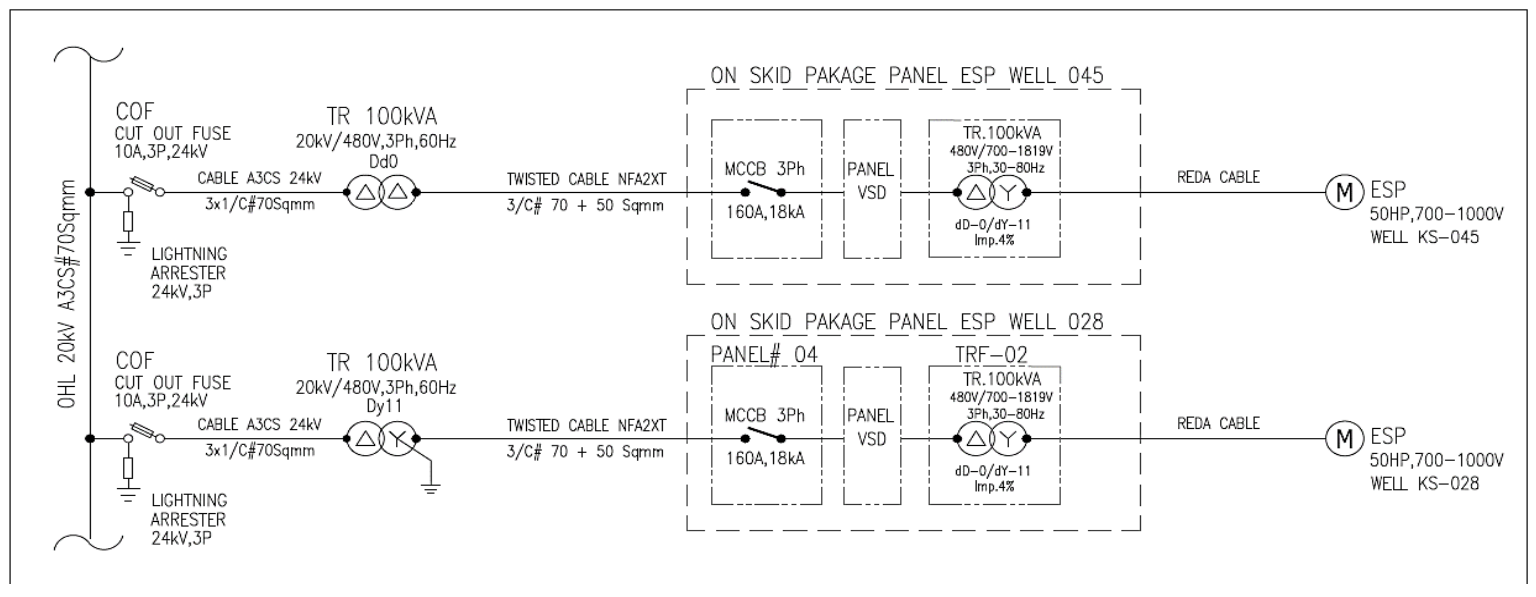

Figure 2. Proposed modification at Kaji-Semoga field (Dy11 with Dd0)

Refer to Table 5, by applying phase shifting transformers method harmonics $I_{5}$ and $I_{7}$ perfectly attenuated become nil (0).

Table 5. Harmonic components at primary Dy11, primary Dd0, and pcc (Dd0 + Dy11)

\begin{tabular}{|c|c|c|c|}
\hline $\begin{array}{c}\text { Harmonic } \\
\text { Component }\end{array}$ & $\begin{array}{c}\mathrm{I}_{\mathbf{H}} \text { at } \\
\text { primary } \\
\text { Dd0 }\end{array}$ & $\begin{array}{c}\mathbf{I}_{\mathbf{H}} \text { at } \\
\text { primary } \\
\text { Dy11 }\end{array}$ & $\begin{array}{c}\mathbf{I}_{\mathbf{H}} \text { at } \\
\mathbf{P C C} \\
\mathbf{D d 0}+ \\
\mathbf{D y 1 1 )}\end{array}$ \\
\hline+1 & $1\left\llcorner 0^{\circ}\right.$ & $1\left\llcorner 0^{\circ}\right.$ & $2\left\llcorner 0^{\circ}\right.$ \\
\hline-5 & $(1 / 5)\left\llcorner 180^{\circ}\right.$ & $(1 / 5)\left\llcorner 0^{\circ}\right.$ & 0 \\
\hline+7 & $(1 / 7)\left\llcorner 0^{\circ}\right.$ & $(1 / 7)\left\llcorner 180^{\circ}\right.$ & 0 \\
\hline
\end{tabular}

It shows that harmonic distortion can be reduced without installing additional protective equipment. Therefore cost to purchase an expensive harmonic filter can be eliminated.

\subsection{Installing Harmonic Filter}

Filters are used when it is necessary to limit harmonic voltages present on a network to a specified low value. Usually the passive harmonic filter will be effective at certain amount of load. Unfortunately, some of our production well with installed ESP seldom experiencing fluctuated fluid 
level. Fluid level affects the consumable load to ESP motor. Therefore, in these cases a passive harmonic filter will be ineffectively installed. Otherwise, an active harmonic filter will cost much more expensive.

Regarding three alternative methods to reduce harmonic distortion effect shown above are compared in the following Table 6. Assuming the size of each equipment are $100 \mathrm{kVA}$ or in its equal units.

Table 6. Comparison table of alternative method for harmonic control in Kaji-Semoga field

\begin{tabular}{|c|c|c|c|c|}
\hline No. & Description & Estimated Cost (USD) & Oigign & Remarks \\
\hline & Purchass Passive HarmonicFilter & 5267 & \multicolumn{2}{|c|}{ imported ineffective during load fluctuation } \\
\hline & Purchase Active Harmonic Filter & 11885 & imported le & effective in certain range of load fluctuation \\
\hline & Purchase Phase-shifting Transformer & 8643 & & ustom made for particular VSD spectifiction \\
\hline
\end{tabular}

\section{CONCLUSIONS}

1. The performance of power system distribution can be improved by reducing harmonic disturbance. Hence, harmonic disturbance can be reduced by oversizing the equipment, installing phase shifting transformers and installing harmonic filter.

2. Phase shifting transformers method is the most economical way out for reducing harmonic distortion; cost to purchase a harmonic filter can be eliminated.

\section{REFERENCES}

Agusman, Candra. 2011. Analisis Perhitungan Rugi-Rugi Daya Transformator karena Harmonik, Universitas Indonesia, Indonesia

Collombet, C., Lupin, J.M., Schonek, J. 1999. Cahier Technique No. 152: Harmonic Disturbances in Networks and Their Treatment, Schneider Electric, France

Firdaus, Himma. 2006. Kombinasi Transformator Dd0 dan Dy1 untuk Mengurangi Distorsi Harmonik Sistem Tenaga Listrik, Puspitek LIPI, Indonesia.
Glover, J. Duncan. 2010. Power System Analysis and Design, Cengage Learning, USA

Hartanto. 2016. Auto; Transformator Geser Fasa untuk Mengatasi Harmonisa VSD, Universitas Indonesia, Indonesia

Lee, C.Y., Lee, W.J., Wang, Y.N., Gu, J.C. 1998. Effects of Voltage Harmonics on the Electrical and Mechanical Performance of a Three-phase Induction Motor,Industrial and Commercial Power Systems Technical Conference IEEE, USA

O'Connell, K., Barret, M., Blackledge J., Sung, A. 2012. Cable Heating Effects due to Harmonic Distortion in Electrical Installation, Dublin Institute of Technology, UK

2014. IEEE Std. 519, Recommended Practice for Harmonic Control in Electric Power Systems,USA 